\title{
35. 17. yüzyıl Fransız tiyatrosunda Doğulu hükümdar imgesi ve Kanuni Sultan Süleyman
}

\section{Özlem KASAP1}

APA: Kasap, Ö. (2021) 17. yüzyıl Fransız tiyatrosunda Doğulu hükümdar imgesi ve Kanuni Sultan Süleyman. RumeliDE Dil ve Edebiyat Araştırmaları Dergisi, (0̈9), 429-436. DOI: 10.29000/rumelide.984836.

\section{$\ddot{0} \mathbf{z}$}

Fransız tiyatrosunun altın çağı olarak anılan 17. yüzyılda, Osmanlı İmparatorluğunu konu alan, daha doğrusu uzam olarak Osmanlı sarayını seçen ve kişilerine "Doğulu" isimler ve özellikler veren oyun yazarları çoğalır. Fransız oyun yazarları ve seyirciler için, o dönem, Osmanlı İmparatorluğu "Doğu"dur (l'Orient) ve yazınsal yapıtlarda Doğu'yu Doğu yapan mutlakıyetin, barbarlığın, zorbalığın, şiddetin hüküm sürdügü saraylar, onların olmazsa olmaz "harem"leri, dinsel gelenekleri ve yasaları ve elbette mutlakıyetin simgesi hükümdarlarıdır. Tüm bu imgeler kimi zaman Batılının kendi imgesini oluşturmak için kullanacağı birer karşı-model olarak yapıtlarda işlenir. Çalışmamızı sınırlayacağımız imge ise, Avrupa ülkelerinde - özellikle Fransa'da - yazınsal yapıtlara, opera ve bale gösterilerine de defalarca esin kaynağı olmuş, çeşitli dönemlerde farklı yorumlarla yeniden ele alınmış olan Kanunî Sultan Süleyman imgesi olacaktır. Kanunî Sultan Süleyman'ın hüküm sürdüğü, özellikle de ilk şehzadesi Mustafa'nın ölümü ile sonlanan döneminin, nasıl ve niçin bir kurgusal malzemeye dönüştüğünü üç tiyatro yapıtından hareketle irdelemeye çalışacağız. Bu oyunlardan ilki, Pierre Mainfray'nin 1621 yılında yayımlanan “La Rhodienne, ou La cruauté de Soliman” (Rodoslu Kadın ya da Süleyman'ın Zalimliği), diğer ikisi de 17. Yüzyıl İtalya'sının en başarılı oyunlarından biri sayılan, İtalyan oyun yazarı Prospero Bonarelli'nin “Il Solimano” adlı oyununun Fransızca yorumlanışı olup, biri Vion D’Alibray'in 1637 tarihli "Le Soliman” (Süleyman) adlı traji-komedisi, diğeri ise 1639'da yayımlanan Jean Mairet'nin “Le grand et dernier Soliman ou La Mort de Moustapha” (Büyük ve Son Süleyman ya da Mustafa'nın Ölümü) adlı trajedisidir. Bu karşılaştırmalı imge çalışmasının sonucunda, halkın imgelemini doğrudan besleyen tiyatro yapıtlarıyla, dönemin toplumsal algısında nasıl bir Doğulu hükümdar imgesi yaratıldığı ve bunun neden bir karşı-model olarak yorumlanabileceği sorgulanacaktır.

Anahtar kelimeler: Kanuni Sultan Süleyman imgesi, Fransız Tiyatrosunda Klasik Dönem, Vion D’Alibray, Jean Mairet, Pierre Mainfray

\section{The image of Suleiman the Magnificent and the oriental ruler in the 17th-century French theater}

\begin{abstract}
In the 17th century, the golden age of French theater, many playwrights used the Ottoman imperial palace as a space for their "western" plays which feature "oriental" characters that can be recognized by their names and properties that are appropriate to them. For the French playwrights, the Ottoman Empire is, at that time the East and this East is represented through its palaces where absolutism, barbarism, tyranny, violence, its "harems", its religious customs and its laws. As for its sovereign, he is the very symbol of Eastern absolutism. In this perspective, this study proposes to study among so many images specific to this East, the image of Suleiman the Magnificent who has inspired many literary works.
\end{abstract}

1 Doç. Dr., Hacettepe Üniversitesi, Edebiyat Fakültesi, Fransız Dili ve Edebiyatı Bölümü (Ankara,Türkiye), ozkasap@hacettepe.edu.tr, ORCID ID: 0000-0003-4649-5689, [Araștirma makalesi, Makale kayıt tarihi: 16.07.2021-kabul tarihi: 20.08.2021; DOI: 10.29000/rumelide.984836]

Adres

RumeliDE Dil ve Edebiyat Araştırmaları Dergisi Osmanağa Mahallesi, Mürver Çiçeği Sokak, No:14/8 Kadıköy - ISTANBUL / TÜRKIYE 34714 e-posta: editor@rumelide.com tel: +90 $5057958124,+902167730616$
Address

RumeliDE Journal of Language and Literature Studies

Osmanağa Mahallesi, Mürver Çiçeği Sokak, No:14/8

Kadıköy - ISTANBUL / TURKEY 34714

e-mail: editor@rumelide.com

phone: +90 5057958124, +90 2167730616 
To understand the reasons which prompted playwrights to use Suleiman by interpreting episodes from his long reign, namely the one relating to the assassination of his first son Mustafa, we will analyze three plays written and performed in the 17th century. The first is a tragedy by Pierre Mainfray. The other two plays are a rewrite in French of the successful play by Italian playwright Prospero Bonarelli, "Il Solimano": a tragicomedy by Vion D'Alibray and a tragedy by Jean Mairet. By comparing the image of Suleiman as it appears in each of these plays, it would be possible to understand the role attributed to this image in its interpretation and its reception but also to explain why this image is considered as a counter-model of "western" identity.

Keywords: The image of Suleiman the Magnificent, French classical theater, Vion D'Alibray, Jean Mairet, Pierre Mainfray

\section{Giriş}

16. yüzyıldan 19. yüzyıla kadar, Müslüman Doğu, Batılılar tarafından gizemli bir “uzak”lık, egzotik ve merak uyandırıcı bir uzam olarak ilgi görmüştür. Tarihsel ve coğrafi açıdan sınırlayıcı olsa da bu ilginin odağında olan Doğu, Osmanlı İmparatorluğu, Doğulu ise “Türk”tür. Kapitülasyonların imzalanması ile ticari, siyasi ve diplomatik ilişkilerin yaygınlaşması sonucunda bu uzam ve Türk imgesi özellikle Fransızların imgeleminde kendine yer bulmuştur (Calefas-Strébelle, 2013: 59). Misyonerler, diplomatlar, gezginler bu kaygı verici olduğu kadar da ilgi uyandırıcı uzamla ilgili gözlemlerini “dünya görüşleri” ve zamanın o uzama yüklediği anlamlarla bezeyerek aktarmışlar, çeşitli imgelerin yaratıcıları ve taşıyıcıları olmuşlardır. Böylece Doğu, Batılının imgeleminde "egzotik", “ürkütücü", "şaşırtıcı", hatta "erotik” yan anlamlarla gelişerek yayılmış; sanatsal ve yazınsal, özellikle de tiyatro yapıtlarında sıklıkla kullanılan bir arka plan haline gelmiştir.

16. ve 17. yüzyıllarda Fransızlarda merak uyandıran ise genel anlamda Türkler ve yaşayışları değil, Osmanlı sultanı, sarayı ve çevresidir. Fransa'da, 1617 yılında tahta geçen ve bakanı Richelieu ile mutlakıyetin temellerini atan Louis XIII gibi, Osmanlı sultanı da Doğudaki mutlakıyetin simgesidir ve kurgusal yapıtlarda öne çıkan bir imge olarak karşımıza çıkar. Bu sultan imgesi de çoğu zaman Kanunî Sultan Süleyman kimliğinde yorumlanır. Kanunî ya da Batılıların Muhteşem olarak adlandırdıkları Süleyman, tarihsel kimliğinin yadsınamaz öneminin yanı sıra, Aristoteles tarafından Poetika'da belirlenmiş ve 17.yüzyla gelindiğinde klasik tiyatro olarak anılacak olan tiyatro kuramlarında tanımlanmış "trajedi” türünün gerekli çoğu unsurunu da yaşamında barındırır.

Bu çalışmada, kurgusal kişi Süleyman'dan hareketle oluşturulan “imge”yi, 17. yüzyılda yayımlanmış ve sahnelenmiş olan üç oyundan hareketle ele almaya ve yorumlamaya çalışacağız: Bu oyunlardan ilki, Pierre Mainfray'nin 1621 yılında yayımlanan “La Rhodienne, ou La cruauté de Soliman” (Rodoslu Kadın ya da Süleyman'ın Zalimliği), diğer ikisi de 17. yüzyıl İtalya'sının en başarılı oyunlarından biri sayılan, İtalyan oyun yazarı Prospero Bonarelli'nin "Il Solimano" adlı oyununun Fransızca yorumlanışı olup, biri Vion D’Alibray'nin 1637 tarihli “Le Soliman” (Süleyman) adlı traji-komedisi, diğeri ise 1639'da yayımlanan Jean Mairet'nin "Le grand et dernier Soliman ou La Mort de Moustapha" (Büyük ve Son Süleyman ya da Mustafa'nın Ölümü) adlı trajedisidir.

\section{7. yüzyıl Fransız tiyatrosu ve saray konulu oyunlar}

17. yüzyılda Fransa'da yazılmış ve oynanmış tiyatro yapıtlarının geneline bakıldığında, Osmanlı İmparatorluğunda meydana gelmiş tarihsel olaylardan esinlenerek yazılmış olan yirmiye yakın trajedi ve traji-komedi olduğu görülmektedir. $\mathrm{Bu}$ oyunların yarısından fazlası ise Kanuni Sultan Süleyman

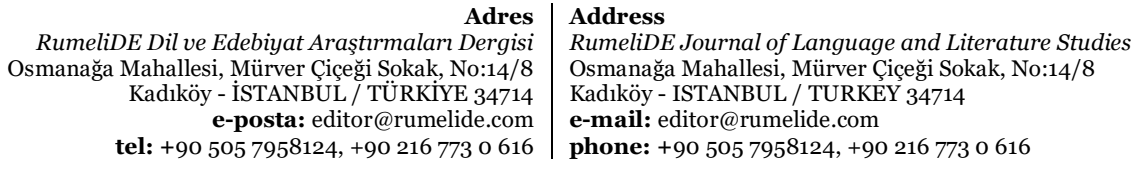


dönemindeki olayların kurgusal anlatımıdır. 17. ve 18. yüzyıllarda Fransız Edebiyatında Doğu kitabının yazarı Pierre Martino, o dönem okuyucuların, adlarını dahi bilmedikleri Doğu ülkelerine aslında hiç de ilgi duymadıklarını, "romanda olduğu gibi tiyatroda da kendilerinin ideal kopyalarının temsil edilmesinden başka bir arzuları" olmadığını belirtiyor (Martino, 1906: 33). Ancak Doğu, kendi uzamlarının karşıtı olduğu, egzotik olduğu için ilginç bir uzam olarak sıklıkla sahneleniyor. Yazılan oyunlar incelendiğinde, Doğu'nun kimi zaman bir arka plan, basit bir egzotik dekor olmaktan öte gitmediği, Doğulu gibi giyinmiş "kahramanların", Doğu saraylarında, Doğu "hikayelerini" birer Batılı gibi yaşadıkları, bu "folklorik" dekor içerisinde Batılı gibi hissedip davrandıkları ve konuştukları görülebilir, seyircinin, "egzotik" bir dekor içerisine yerleștirilmiş "kendi" temsilini izlemekten keyif aldığı söylenebilir. Egzotizm, trajedi yazarı açısından da, oyununun konusunu, antikiteden almak yerine², uzamda uzaklaşarak o uzak, bilinmeyen ve gerçekte pek de bilinmek istemeyen gizemli ve ürkünç Doğu'dan alarak farklı ve popüler bir eser yaratma olanağı sağlamaktadır.

17. yüzyılda yazılmış ve sahnelenmiş egzotik oyunlarda "turqueries" araştırması yapan Sylvie Requemora bu oyunların birer tür, hatta alt tür olmadıklarını ve "minör" olarak nitelendirilebileceklerini belirtirken, tarihsel kaynaklarına göre altı döneme ayırır. Bu dönemlerden ilki, Yıldırım Bayezid ve Timur arasındaki savaşı, sonuncusu ise Gençosman olarak bilinen II. Osman'ın hükümdarlığının son dönemlerini konu aldığından çalışmamızın kapsamı dışındadır ancak diğer dört dönem de doğrudan Süleyman ile ilintilidir. Bunlar sırasıyla: Hürrem - Roxelane'ın yükselişi (en az Süleyman kadar kullanılmış bir kurgusal oyun kişisi olarak karşımıza çıkar), Süleyman'ın oğullarının taht kavgası (ele alacağımız iki oyunun konusunu oluşturan Mustafa'nın ölümü de bu dönem içerisinde yer alır), İbrahim'in yükselişi ve son olarak, Hürrem'ın yer almadığı̆, genç bir çifte, despot, barbar, zalim bir hükümdar rolündeki Süleyman tarafından eziyet edilmesi. Süleyman ekseninde yazılmış bu oyunlardan yedisi trajedi, üçü de traji-komedidir (Requemora, 2004: 133).

\section{Yazınsal bir imge olarak "Kanunî Sultan Süleyman"}

Tarihsel gerçekliğin kurgusal olan ile harmanlandığı bu oyunlar çeşitli bilimsel yaklaşımlarla incelenmiş, incelenmeye devam etmektedir. Bu çalışmada amacımız, "kahramanı" trajedinin kaçınılmaz sonu olan ölüme mahkum eden Doğulu, zorba hükümdar imgesi olarak kurgusallaştırılan Süleyman'ı dramatürjik açıdan ele almak ve 17.yüzyıl Fransa'sında nasıl alımlandığını, mutlakıyet anlayışına, Fransız kimliğinin oluşumuna ve şiddet, kabalık gibi feodal özelliklerden arınılmasına nasıl katkı sağlamış olabileceğini sorgulamaktır.

Aristoteles Poetika'da, sanatları taklit ettiklerine göre şöyle ayırır: İyileri taklit edenler, kötüleri taklit edenler. Trajedinin ortalamadan daha iyi kişileri, komedinin ise ortalamadan daha kötü kişileri taklit ettiğini söyler (Aristote, 1870: 9). Süleyman, komedilere konu olacak "utanç verici", "gülünç" zaaflar taşımadığından komedi kişisi olarak taklit edilemez ancak zalim ve despot olduğundan, taklit edilecek "iyi" bir model de değildir. Dolayısıyla genelde ne trajedilerin, ne de mutlu bir son ile biten traji-komedilerin "kahramanı" olarak kurgulanmaz. Süleyman daha çok, Antik Yunan trajedilerindeki Tanrıların, kahramanları ölüme sürükleyen değiştirilemez "kader"in oynadığı role benzer bir rol oynar. Oysa, Tanrının yeryüzündeki gölgesi olarak anılsa da Süleyman Tanrı değil, hükümdardır ve hükümdar/kral ethos'unu

2 Klasik tiyatroda, özellikle de trajedide, konunun, olabildiğince antik Yunan ya da Roma mitolojisinden, antik dönem yazarlarının trajedilerinden ya da Yunan veya Latin tarihçilerin aktardıkları olaylardan esinlenmesi beklenir. 17. yüzyıl tiyatrosunun en önemli trajedi yazarlarından olan Racine, Bajazet - Bayezid- oyunu ile bu kuralı ihlal eder (olay 17. yüzyılda Osmanlı İmparatorluğu'nda geçtiğinden "çağdaș" bir tarihsel olaydan esinlenir) ve oyuna yazdığı ikinci önsözde coğrafi uzaklığın, zamansal uzaklığa eşdeğer olduğunu savunur; kahramana duyduğumuz saygının bizden uzak olduğu ölçüde olanaklı olduğunu belirterek, ülkelerin birbirlerine olan uzaklıklarının bu gerekli mesafeyi yarattıklarını ifade eder.

$$
\text { Adres | Address }
$$

RumeliDE Dil ve Edebiyat Araşturmaları Dergisi Osmanağa Mahallesi, Mürver Çiçeği Sokak, No:14/8 Kadıköy - İSTANBUL / TÜRKIYE 34714 e-posta: editor@rumelide.com tel: +90 505 7958124, +902167730616

RumeliDE Journal of Language and Literature Studies Osmanağa Mahallesi, Mürver Çiçeği Sokak, No:14/8 Kadıköy - ISTANBUL / TURKEY 34714 e-mail: editor@rumelide.com phone: +90 5057958124 , +90 2167730616 
taşır. Ancak, kurgusal bir karaktere dönüştürüldüğü oyunlar kendisinin "geleneksel" bir kral olmadığını, "zorba bir Türk hükümdar" olarak sahneye konulduğunu gösterir ve kimi zaman erdem sahibi, adil ve asil kral özellikleri sergilese de uygunluk kuralı gereği, o dönem "zorbalara ve Türklere" atfedilen iki tutkuya esir olduğu gözlemlenir: "bir yandan meşhur libido dominandi, erk tutkusu, bir yandan ise aşk tutkusu" (Chataigner, 2014: 2). David Chataigner, Süleyman'ın oyunlarda "zaylf" bir hükümdar olarak temsil edildiğine dikkat çekerken, tutkularına yenik düşmek ve akıl yolunu seçmek arasında gidip gelişini Apostolidès'in kralın çift bedeni teorisi ile açılkar: "Bu doktrin (...) gerçek kişi olan hükümdar ile persona ficta, yani Devletin cisimleşmiş hali olan hükümdar arasında ayrım yapar. Aynı beden içinde kralı Kraldan ayırt etmeyi sağlar. İlki, gerçek insan, etten bir bedene sahiptir ve tebaası ile aynı olumsallı̆ga tabidir; ikincisinin ise simgesel bir bedeni vardır ve ölmez." (Chataigner, 2014: 1). 17. yüzyıl Fransız oyun yazarlarının kaleminde Süleyman'ın çoğu zaman bu iki beden arasında bölünmüş olduğunu, bu bölünmüşlüğün ise hüküm sürmesine engel olduğunu, tereddütleri içinde erkini ve görkemini kaybettiğini görmek olanaklıdır. Bu unsur aslında Süleyman'ın, hem temsil hem de alımlama anlamında etkisizleştirilmesi, Batıdaki emsallerinden, akıl, sağduyu, adalet, eşitlik gibi özellikleri barındırması beklenen kral ethos'undan uzaklaștırılmasına katkı sağlar.

\section{“La Rhodienne, ou La cruauté de Soliman” (Rodoslu Kadın ya da Süleyman'ın Zalimliği)}

Pierre Mainfray'nin 1621 yılında yazdığı bu oyun, Jacques Yver'in 1572 tarihli Printemps, Histoire tragique des amours d'Eraste et de Perside öyküsünün yeniden yazımıdır. Yver'in öyküsü, asil aileden gelen iki genç insanın trajik aşklarının anlatımı ve asillerin, prenslerin yaşadıkları baht dönümü (péripétie) üzerine bir sorgulamadır. Zorba bir hükümdarın yıkıcı tutkusu ise öykünün sonunu hazırlar. Tıpkı Yver gibi, Mainfray de oyununu baht dönümü üzerine kurmuștur (Campangne, 2005: 213) ancak oyun aslında iki farklı okumayı olanaklı kılar. Mainfray, hem Perside kişisini hem de Süleyman kişisini başlı̆a koyarak bu iki okumanın önünü açar. Oyunun kahramanı cesur, iyi savaşçı, erdemli Rodoslu şövalye Eraste iken, Perside de sevdiği ve sevildiği ancak talihsizlikler ve yanlış anlamalar sonucunda ayrı düştüğü Rodoslu "demoiselle"dir. Bu karşılıklı sevginin tersine dönmesine (revers de fortune) neden olan olaylar Perside'in Eraste’a hediye ettiği mücevherin yanlışlıkla başkasının eline geçmesi ve Eraste'ın bir başka şövalyeyi öldürerek Rodos'tan sürgün edilmesidir. Dramatik gerilimi artırmak için oluşturulan üçgeni tamamlayacak Süleymen oyun kişisi, Eraste'ın Süleyman'ın ordusunda savaşmaya başlaması, Rodos'un fethedilmesi ve Perside'in Süleyman'ın sarayına getirilmesi ile hikayeye dahil olacaktır. Oyunun başlığından da anlaşılacağı gibi bu oyun kişisi, çok açı bir zorba imgesinde resmedilmekte ve onun zalimliği oyundaki ikinci ve üçüncü baht dönümlerini tetiklemeye yaramaktadır.

Tutkusuna karşılık alamayan ve Perside'in Eraste’a duyduğu aşkı öğrenen Süleyman iki genci evlendirmeye karar verir ve Rodos'a vali atadığı Eraste ile birlikte Rodos'a yerleşmelerine izin verir. Talihsizlikler sonucu ayrılmış olan çift böylece tekrar bir araya gelmiş ve mutluluğa kavuşmuştur. Elbette bu davranış oyunun başlığının da gösterdiği gibi Süleyman'ın “Doğulu zorba hükümdar” (tyran oriental) imgesine aykırıdır. Poetika'da baht dönümü ve / veya tanıma (reconnaissance) ile biten trajediler "karmaşık" (implexe) olarak tanımlanır ve iyi birer örnek olarak verilir (Aristote, 1870: 17). Görülüyor ki Mainfray, mutlu bir sona gittiği izlenimi veren oyununa baht dönümü ve tanımanın bir arada kullanıldığı bir son yazarak klasik kurguyu başarılı bir şekilde oluşturur. Erdemli davranışından pişmanlık duyan Süleyman, danışmanlarından da etkilenerek, bir haberci gönderir ve Eraste'ı saraya çağırarak öldürtür. Rodos'u ele geçirip Perside'i almaya karar verir ancak Eraste'ın zırhını giymiş olan Perside Rodos surları üzerinde kendisine meydan okuyunca, paşalarının öğütlediği gibi kim olduğunu bilmeden ölüm emrini verir. Rodos zalimce ele geçirildikten sonra Süleyman'ın, zırhın içindekinin Perside olduğunu anlaması da klasik anlamda bir "tanıma"dır. Mainfray, Süleyman'ın zalimliğini pekiştirmek için ise danışmanlığını yapan paşalardan biri olan Bustor'u idam ettirir.

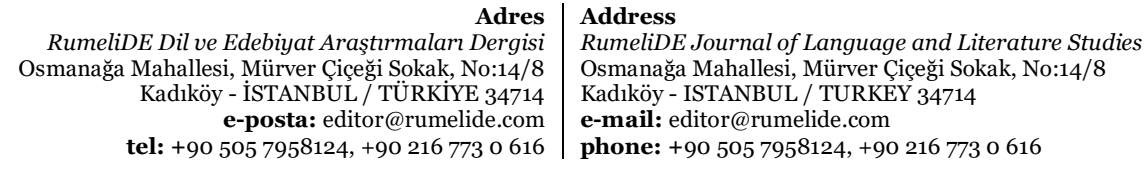


"Uyandırdığı acıma ve korku duygularıyla ruhu tutkulardan temizleme" amacı güden katharsis, oyunun erkek ve kadın kahramanlarının ölümü, Süleyman'ın pişmanlığı, Bustor'un idamı ile gerçekleşir.

Yver'in öyküsündeki anlatı unsurlarının tüm ayrıntılarını sahneye taşıyan Mainfray, dönemin seyircisinin beklentisini karşılar aslında. Perside'in ölümünü sahne dışında gerçekleştirip anlatabilecekken, yer birliği kuralını ihlal etmek pahasına kurguyu Rodos'a taşır ve genç kadının cesur ölümünü, Rodos'un ele geçirilişini ve Süleyman'ın pişmanlığını gösterir (Campangne, 2005: 218). Özellikle Perside'in ağzından anlatılan şiddet ve zalimlik, "kargalara yem olarak atılan cesetler", "kan nehirlerinde yüzen bedenler" gibi görsel imgeler ise 16. yüzyılda yazdığı “L’art poétique françois” ile bilinen Laudun D'Aigaliers'nin “Trajediler, vahşi oldukları ölçüde kusursuzdurlar." cümlesini doğrular (Campangne, 2005: 218).

\section{"Le Soliman" (Süleyman) - "Le grand et dernier Soliman ou la mort de Moustapha” (Büyük ve Son Süleyman ya da Mustafa'nın ölümü)}

İlki, Mainfray'nin oyunundan on altı yll sonra, ikincisi de on sekiz yll sonra yazllan ve sahnelenen bu oyunlar, tarihsel çerçeve ve Süleyman imgesi açısından La Rhodienne oyunundan ayrılır. Bu iki oyun da, Mustafa'nın 1553'de öldürülmesini konu alan ilk oyunlardan (Le Thiec, 1996: 139), Prospero Bonarelli'nin 1619 yllında yayımlanan ve büyük başarı elde eden Il Solimano oyununun yeniden yazımıdır. İkisini de incelemek istememizin nedeni, Le Soliman oyununun yazarı Vion D'Alibray'nin, bu oyundan bir yıl önce Corneille'in Le Cid oyunuyla gündeme oturan traji-komedi tartışmaları daha sürerken, tarihsel gerçekliği de değiştirerek mutlu sonla biten bir traji-komedi ortaya koymasıdır. Bu çalışma çerçevesinde, bu mutlu sonun Süleyman kişisinin kurgusallaşmasını nasıl etkilediğini, imgede bir farklılık yaratıp yaratmadığını sorgulamak yerinde olacaktır.

Oyunlara kaynak olmuş tarihsel evrelerden belki de trajediye en uygun olanı uyarlayan D'Alibray ve Mairet, Aristoteles'in Poetika'nın 14. bölümünde vurguladığı gibi, kurguyu "dehşet ve acıma duygularını" en üst seviyeye çlkarabilecek bir çerçeveye yerleștirirler. İlgili bölümde Aristoteles "Felaket birbirini seven insanların başına gelirse; bir kardeș bir kardeși, bir oğul babasını, bir anne oğlunu, bir oğul annesini öldürmek üzereyken" seyircide heyecan yaratılır der (Aristote, 1870: 22). Hürrem'in yükselişi ve Mustafa'nın öldürülmesi, Batılı yazarların özellikle kurgusallaştırdıkları ve ilgi gören epizodlardır. Hürrem'ın tiyatro yapıtlarında ve romanlarda üslendiği rol 17. yüzyıldan sonra farklılaşacak ve harem uzamının kullanılmaya, cariyeler arası entrikaların işlenmeye başlamasıyla "erotik" yan anlamlar da eklenerek seyircinin / okuyucunun değișen beğenilerine hitap etmeye başlayacaktır. Bu oyunlarda ise rolü henüz kısıtlıdır. Oyunda, Süleyman'ın yaşayan en büyük oğlu Mustafa'nın tahta geçtikten sonra kardeş katli yasası gereği oğullarını öldüreceğinden endișe duyan Roxelane (Hürrem), Rüstem'in de yardımıyla bir komplo kurup, Süleyman'ı Mustafa'nın hain olduğuna ve Pers Şahı ile işbirliği içinde olduğuna inandıracak, ölümüne yol açacaktır.

Mainfray'nin oyununa göre tarihsel gerçekliğe daha yakın, daha karmaşık bir kurgu, daha çok sayıda oyun kişisiyle bu iki oyun da tarihsel oyun türüne daha fazla yaklaşırlar ve Aristoteles'in tarihçi ve oyun yazarı arasında belirlediği farklılıktan ilerleyerek olmuş olanı değil, klasik tiyatronun benzerlik, inandırıcılık kuralları çerçevesinde "olabilecek olanı" anlatırlar. Elbette de bu olabilecek olanın sınırları, Roxelane'ın doğumda çocukların değiştirilmesi sonucunda Mustafa'nın annesi olduğunun ortaya çıkması ile esnetilir, bu kurgu, Antik Yunan trajedilerinde de sıklıkla kullanılan bir baht dönümü ve tanıma unsuru olarak belirir. D’Alibray'nin mutlu bir son ile Mustafa'nın hayatını bağışladığı oyununda bu gerçek zamanında ortaya çıkar ve seyirci, oyun boyunca bu masum kahraman için duyduğu kaygı ve dehşetten kurtulur. Ancak, Mairet, kaynağına sadık kalarak baht dönümü ve tanıma unsurunu oyunun sonunda trajedi kurallarına uygun

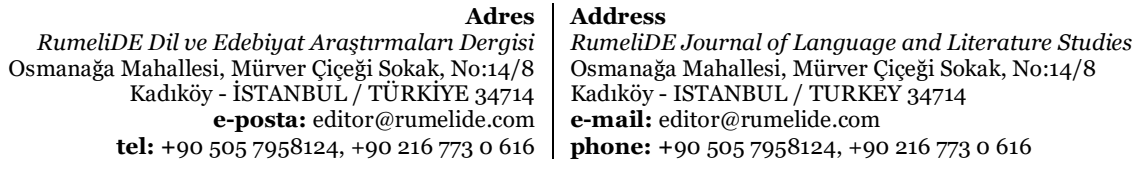


olarak kullanır, Roxelane Mustafa'nın oğlu olduğunu çok geç öğrenir, Süleyman ise hem haksız yere öldürttügü oğlu, hem de bu ölüm haberi sonrasında intihar eden Roxelane'ın yasını tutarak seyircide "acıma" duygusunu uyandırır.

Vion D’Alibray'nin Soliman oyununun açılamalı bir baskısını hazırlayan Marie-Pauline Martin, Bonarelli'nin Il Solimano oyununda Süleyman'ın oyunun gerçek kahramanı olarak değerlendirilmesi gerektiğini, seyircinin Mustafa için korkarken, asıl katharsisi, Süleyman'ın oğlunun ve karısının kaybı sonucunda en büyük baht dönümünü deneyimleyerek yaşadığını belirtiyor ve D'Alibray'nin, hem Süleyman'ı, hem de Mustafa'yı kahraman olarak sahneye koyduğunu, her iki oyun kişisinin de eşit derecede iç çatışma yaşadığına dikkat çekiyor.

Süleyman imgesi olarak değerlendirildiğinde, gerek traji-komedide, gerekse trajedide karşımıza çıan hükümdarın, Mainfray'nin sahneye koyduğu ve Osmanlı sultanı olduğunu seyirciye göstermek için hem kendi ağzından, hem de paşalarının ağzından Osmanlı seferlerini, zaferlerini, Batıya saldığı korkuyu hatırlatmak zorunda olduğu Süleyman'dan daha derinlikli ve çalışılmış olduğu görülebilir. Bu derinlik, özellikle yaşadığı iç çatışmasının yoğunluğu onu, Apostolidès'in tanımladığı kralın çift bedeninden, gerçek olanına daha fazla yaklaştırır. Seyircinin Süleyman'ı ölümsüz kral bedeninde değil, ölümlü, acı çeken insan bedeninde görmesini sağlar. D'Alibray'nin oyununda bu iç çatışmanın sağduyu yönünde seyretmesi ve Mustafa'nın hayatının bağışlanması ise Süleyman'ı, aşk tutkusunun ya da erk tutkusunun ağır bastığı zorba Süleyman karşısında "iyi hükümdar" imgesine daha çok yaklaştırır.

\section{Sonuç}

“Turqueries” araştırmaları ile bilinen Sylvie Requemora'nın makalesinde, J. Emelina'dan alıntıladığı FarWest / Far-East benzetmesi son derece ilginçtir: "Nasıl ki şehirleșen ve medenileșen 20. yüzyll, imgesel düzlemde aşırılığını yansıtmak için Vahşi Batı'yı yaratmıştır, (...) 17. yüzyıl da "dürüst insan" (honnête homme), "saray insanı" için hem yakın, hem de uzak olan bir Vahşi Doğu yaratmıştır." (Requemora, 2004: 148). Emelina, Vahşi Doğu'nun yakınlığını, kullanılan dilden, görgüden ve duygu analizlerinden aldığını, uzaklığını ise tutkuların şiddet düzeyinden, kahramanlığın ulaştığı dehşet ve vahşet düzeyinden aldığını da belirtir. Ne kadar egzotik, uzak, akıl almaz da olsa yaratılan bu Doğu ve Doğulu imgeleri aslında onu alımlayan seyirci için yakındır çünkü o uzama ve uzamın temsilcilerine atfedilen tutkular da, şiddet de, vahşet de, mutlakıyet de bilinmez değildir.

Bu bağlamda, 17. yüzyıl Fransız tiyatrosunda yaratılan "zorba Doğulu hükümdar" imgesi olarak karşımıza çıkan Süleyman imgesi de aslında çok da uzak bir imge olmadığından ilgi çeker. Zorbalığının ve onun doğurduğu vahşetin sahneye konulması, oyun yazarları için, toplumda karşıllı̆ı bulunan "zorbalık" ve "mutlakıyet" kavramları üzerine bir sorgulama yöntemi olarak değerlendirilebilir. Dominique Carnoy'nın 17.yüzyılda Fransa'da İslamın Temsilleri yapıtına göndermede bulunan Requemora, mutlakıyetin 17. yüzyıl okuyucuları için yeni olmadığını ve bu düşünceyi geliştirmenin gereksiz olduğunu ancak, Doğulu hükümdarların mutlakıyetini tanımlamanın, Fransa kralları ile aralarında sınırın nerede çekildiğini göstermek açısından önemli olduğunu belirtiyor. Bu çerçevede, Müslüman Doğulu zorba hükümdar, Batılı Hristiyan "iyi" kralın karşı-modeli olarak resmediliyor tıpkı Osmanlı sarayının karanlık yüzünün, Fransız sarayının aydınlık yüzünün karşı-modeli olduğu gibi. Ancak Requemora, "zorbalığın" sahnelenmesinin gördüğü ilgiyi, Richelieu'nün etkisiyle merkezileșen otoriter yönetim karşısında duyulan endişeye de bağlıyor ve trajedinin, krallığın nasıl icra edilmesi gerektiğinin temsil edildiği bir okul olduğunu da ileri sürüyor (Requemora, 2004: 137). 17. yüzyll tiyatrosu, Doğu imgesi, egzotizm alanındaki en önemli araştırmacılardan Michèle Longino ise, klasik tiyatroda Türk imgesine duyulan ilgiyi, Fransız kimliğinin,

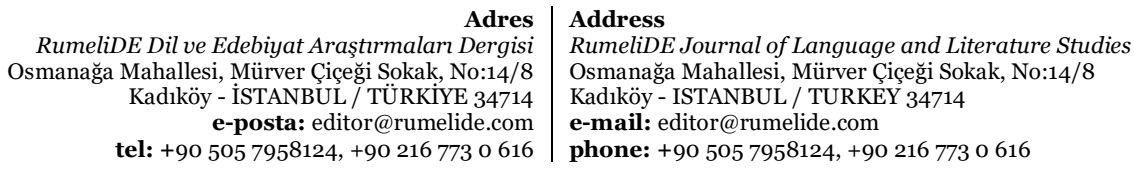


“öteki”nin sağladığı egzotizm karşısında oluşmasına katkı sağlaması ile açıklıyor. Dahası, bu imgenin, seyircide kültürel bir dayanışma geliştirerek ulusal bir üstünlük duygusu doğurduğunu da ekliyor (Longino, 1997: 35 - 39). Bu imge bir bakıma da, Fransa'da asil sınıfta yaşanan değişimi de kolaylaştırmaya, şiddetin “öteki”ye yansıtılarak arınma yöntemi olarak kullanılıyor. Bu konuda, Calefas-Strébelle, Türk imgesinin taşıdığı savaşçı özelliklerin, görkem, zorbalık, şiddet gibi unsurların feodal özelliklerle benzerlik gösterdiğini ve saray asaletine geçiş yapan Fransız asillerinin bunu “öteki”ye atfederek, bu özellikleri geride bıraktıklarının altını çiziyor. Bu şekilde aristokrasinin bir katharsis yaşadığını, barındırdığı feodal ve yeni ulusal kimlikle bağdaşmayan şiddet ve vahşetten arındığını belirtiyor. (Calefas-Strébelle, 2013: 60 - 62). Bu yoruma, Süleyman'ın 46 yıllık uzun ve Osmanlı açısından başarılı hükümdarlığının Batı'da izleri kalan korku ve dehşetten arınmayı da sağlamış olabileceği eklenebilir.

Sonuç olarak, trajedinin temel işlevinin insana insanı göstermek, insanı kendi içindeki "kötülüklerden", "aşırılıklardan" arındırmak olduğunu, tiyatro kişilerinin bu kötülük ve aşırılıkları temsil ederken çektikleri acıyla paroxysme'e ulaşıldığını, bu kötülük ve aşırılıklar "uzak" uzamlarda, "öteki”nin bedeninde yaşansa da insana ait olduğundan yakın olduğunu ve seyircide karşıllk bulduğunu söyleyebiliriz.

\section{Kaynakça}

And, M. (1999). Tiyatro, Bale ve Opera Sahnelerinde Kanuni Süleyman Imgesi, Dost.

Aristote (1870). Poétique d'Aristote, Traduit par Ch. Batteux, Imprimerie et Librairie classiques. http://gallica.bnf.fr/ark:/12148/bpt6k70607g.r=po\%C3\%A9tique+aristote.langEN

Calefas-Strébelle, A. (2013). Tétes de Turcs et Grands Seigneurs: pratique de la violence chez les Turcs et dans l'aristocratie française aux XVIe et XVIIe siècles. L'Esprit Créateur, 53(4), 59-70. https://www.jstor.org/stable/10.2307/26378866

Campangne, H. (2005). De l'histoire tragique à la dramaturgie: Mainfray et Desfontaines lecteurs de Jacques Yver. Dix-septième siècle, 227 (2), 211-226. doi:10.3917/dss.052.0211.

Chataigner, D. (2014). Représentation de la tyrannie dans les tragédies à sujet turc du Grand Siècle français. https://lettres.sorbonne-universite.fr/sites/default/files/media/2020

01/crht_david_chataignier_representation_de_la_tyrannie_dans_les_tragedies_a_sujet_turc_du_gran d_siecle_francais-2.pdf

Le Thiec, G. (1996). Le complot de Roxelane. La Soltane de Gabriel Bounin (1561) et Il Solimano de Prospero Bonarelli (1619) : deux tragédies politiques à la cour de France et dans la Florence des Médicis. École Française de Rome, 137-161. www.persee.fr/doc/efr_02235099_1996_act_220_1_4980

Longino, M. (1997). Politique et théâtre au XVII siècle: les Français en Orient et l'exotisme du Cid. Courcelles, D. d. (Ed.), Littérature et exotisme, XVIe-XVIII siècle. doi :10.4000/books.enc.1041

Longino, M. (2013). Constantinople: The Telling and the Taking. L'Esprit Créateur, 53(4), 124-138. https://www.jstor.org/stable/26378871

Mainfray, P. (1621). La Rhodienne, ou La cruauté de Soliman, Imprimeur du Roy. https://gallica.bnf.fr/ark:/12148/bpt6k71547p.image

Mairet, J. (1639) Le grand et dernier Solyman, ou La mort de Mustapha. https://gallica.bnf.fr/ark:/12148/bpt6k5609755m.pdf

Martin, M-P. (2010). Le Soliman. Tragi-comédie, Bibliothèque dramatique. http://bibdramatique.humanum.fr/dalibray_soliman

Martino, P. (1906). L'Orient dans la littérature française au XVIIe et au XVIIIe siècle, Librairire Hachette. http://openlibrary.org/books/OL23446532M/L\%270rient_dans_la_litt\%C3\%A9rature_fran\%C3\% A7aise_au_XVIIe_et_au_XVIIIe_si\%C3\%A8cle

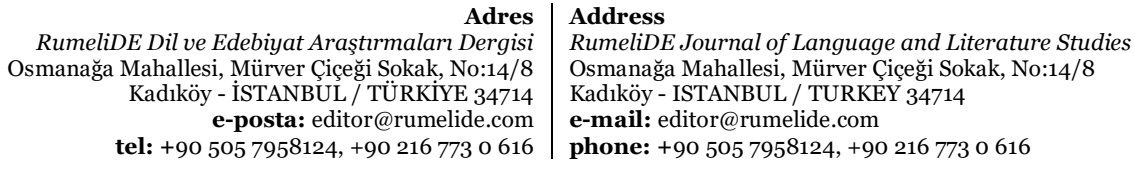


436 / RumeliDE Journal of Language and Literature Studies 2021.S9 (August)

The image of Suleiman the Magnificent and the oriental ruler in the 17th-century French theater / Ö. Kasap (pp. 429-436)

Requemora S. (2004). Les turqueries : problèmes de définition d'une vogue théâtrale en mode mineur. Littératures classiques (51) 133-151. doi : https://doi.org/10.3406/licla.2004.2003

Adres $\mid$ Address

RumeliDE Dil ve Edebiyat Araştırmaları Dergisi $\quad$ RumeliDE Journal of Language and Literature Studies Osmanağa Mahallesi, Mürver Çiçeği Sokak, No:14/8 $\quad$ Osmanağa Mahallesi, Mürver Çiçeği Sokak, No:14/8 Kadıköy - İSTANBUL / TÜRKIYE 34714 Kadıköy - ISTANBUL / TURKEY 34714

e-posta: editor@rumelide.com $\quad$ e-mail: editor@rumelide.com

tel: +90 505 7958124, +90 216773 o 616 phone: +90 505 7958124, +90 2167730616 